DOI:10.22337/2587-9618-2018-14-—-१०-००

\title{
LIRA-SAPR PROGRAM FOR GENERATING DESIGN MODELS OF RECONSTRUCTED BUILDINGS
}

\author{
Maria S. Barabash, Maryna A. Romashkina \\ 1 "LIRA SAPR" Ltd, Kiev, UKRAINE \\ ${ }^{2}$ National Aviation University, Kiev, UKRAINE
}

\begin{abstract}
The paper deals with technique of simulation for buildings at maintenance stage with account of changes in structural model during reconstruction. The authors suggest algorithm for linear and nonlinear analysis of structures in LIRA-SAPR program with account of erection process. Generation of design models for reconstructed buildings are illustrated with real examples from design practice (reconstruction of 3-storey office building with overstorey; reconstruction of 5-storey hostel with built-in nonresidential premises when floor slabs are changed; reconstruction of building with account of defects that were detected and strengthening that was made; reconstruction of 9-storey residential building where gas was exploded, with account of defects that were detected and strengthening that was made).
\end{abstract}

Keywords: reconstruction, stress-strain state, strengthening, design model, erection, assemblage, disassemblage

\section{ИСПОЛЬЗОВАНИЕ ПРОГРАММНОГО КОМПЛЕКСА ЛИРА-САПР ПРИ СОСТАВЛЕНИИ РАСЧЕТНЫХ СХЕМ РЕКОНСТРУИРУЕМЫХ ЗДАНИЙ}

\author{
М.С. Барабаш, М.А. Ромашкина \\ ${ }^{1}$ ООО «ЛИРА САПР, г. Киев, УКРАИНА \\ ${ }^{2}$ Национальный авиационный университет, г. Киев, УКРАИНА
}

\begin{abstract}
Аннотация: Рассматривается методика моделирования зданий в эксплуатационной стадии с учетом изменяющейся конструктивной схемы в процессе реконструкции. Предлагается алгоритм расчета конструкций в линейной и нелинейной постановке с учетом процесса возведения в программном комплексе ЛИРА-САПР. Создание расчетных схем реконструируемых зданий проиллюстрированы на примерах реальных задач из проектной практики (реконструкция 3-х этажного административного здания с надстройкой этажа; 5-ти этажного здания общежития со встроенными нежилыми помещениями при замене плит перекрытия; реконструкция здания с учетом выявленных дефектов и выполненного усиления; реконструкция жилого девятиэтажного здания, в котором произошел взрыв газа, с учетом выявленных дефектов и выполненного усиления).
\end{abstract}

Ключевые слова: реконструкция, напряженно-деформированное состояние, усиление, расчетная модель, возведение, монтаж, демонтаж

\section{INTRODUCTION}

Reconstruction is significantly different from new construction and has its own peculiarities in the design. Reconstruction, redevelopment and modernization of buildings and structures require strengthening of bearing elements in order to keep the ability of buildings and structures as a whole to bear additional loads.

It should be noted that in recent years the number of emergency cases during reconstruction has significantly increased [1]. One of the main reasons of accidents is the following: there is no unified and 'adequate' method for computing stress-strain state of the 
structure when the design model is modified as a result of assemblage/disassemblage of the load-bearing elements in building during reconstruction.

To reduce the risk of emergency during reconstruction, it is necessary to investigate and predict the stress-strain state of the structure [24]. Numerical modelling will enable the user to evaluate the consequences that may affect bearing capacity of the building as a whole.

\section{MAIN BODY}

Methods for computing buildings and structures during reconstruction are constantly improved. Modelling of behaviour of the building structures and generation of correct design models were studied by several scientists as V. Banakh $[5,6]$, A. Gorodetsky [4], E. Gorokhov, A. Dykhovychny, N. Zotsenko, S. Klovanich, V. Kulyabko, A. Perelmuter [7], V. Slivker, R.L. Taylor, O.C. Zienkiewicz, etc.

However, up to now correct modelling of behaviour of existing buildings and structures under reconstruction has not been sufficiently studied. For reconstructed objects, there are many features that should be considered in analysis of stress strain state: damage to structural elements of the building before reconstruction (cracks, reduction of the cross section of elements); deformations of the base that are present at the time of reconstruction; change in service conditions of the building, change in engineering and geological conditions; changes in the initial design model of the building in the process of reconstruction, etc.

Therefore, the urgent task is to create methods for generation of adequate design models for buildings under reconstruction. Modern software packages that simulate the behaviour of structures at different stages of their life cycle, and take into account the changes in stress strain state during reconstruction enable the user to correctly evaluate the bearing capacity of building structures.

The real stress-strain state of the elements of bearing structural systems may be determined when a number of numerical experiments are conducted:

- to model erection process, when the stress strain state is determined for all design models corresponding to the stages of construction, and the model of the ready structure 'keeps memory' about the history of its construction;

- to model loading process, for example, for $\mathrm{RC}$ structures it is possible to trace initial stages of linearly elastic behaviour of structure, the stages of successive formation and propagation of cracks in concrete, the stages of development of plastic strain in compressed concrete and tensioned reinforcement, the stages prior to destruction, and full or partial unloading at any of these stages and further loading [8-10].

Peculiarities of modelling such processes and the capabilities of modern software used in this case will be illustrated with examples of solving real problems from design practice based on LIRA-SAPR program.

\section{GENERATION OF DESIGN MODELS FOR RECONSTRUCTED BUILDINGS}

In LIRA-SAPR 2018, the bearing capacity of the cross sections of bar and plate elements is analysed with regard to real reinforcement pattern, according to the current regulatory and normative documents valid at the time of design process.

For the above-mentioned purpose, it is possible to define the pattern of reinforcing items in the bar and plate elements either within the whole design model or for individual elements (Fig. 1). When generating design model of the building where the loads from the superstructure storeys will be transferred to the existing building, the actual location of the reinforcement items is defined in the existing building elements. After checking the bearing capacity of sections with a specified reinforcement, according to building codes, the safety factor of the bearing capacity in each element of the plates and in each section 


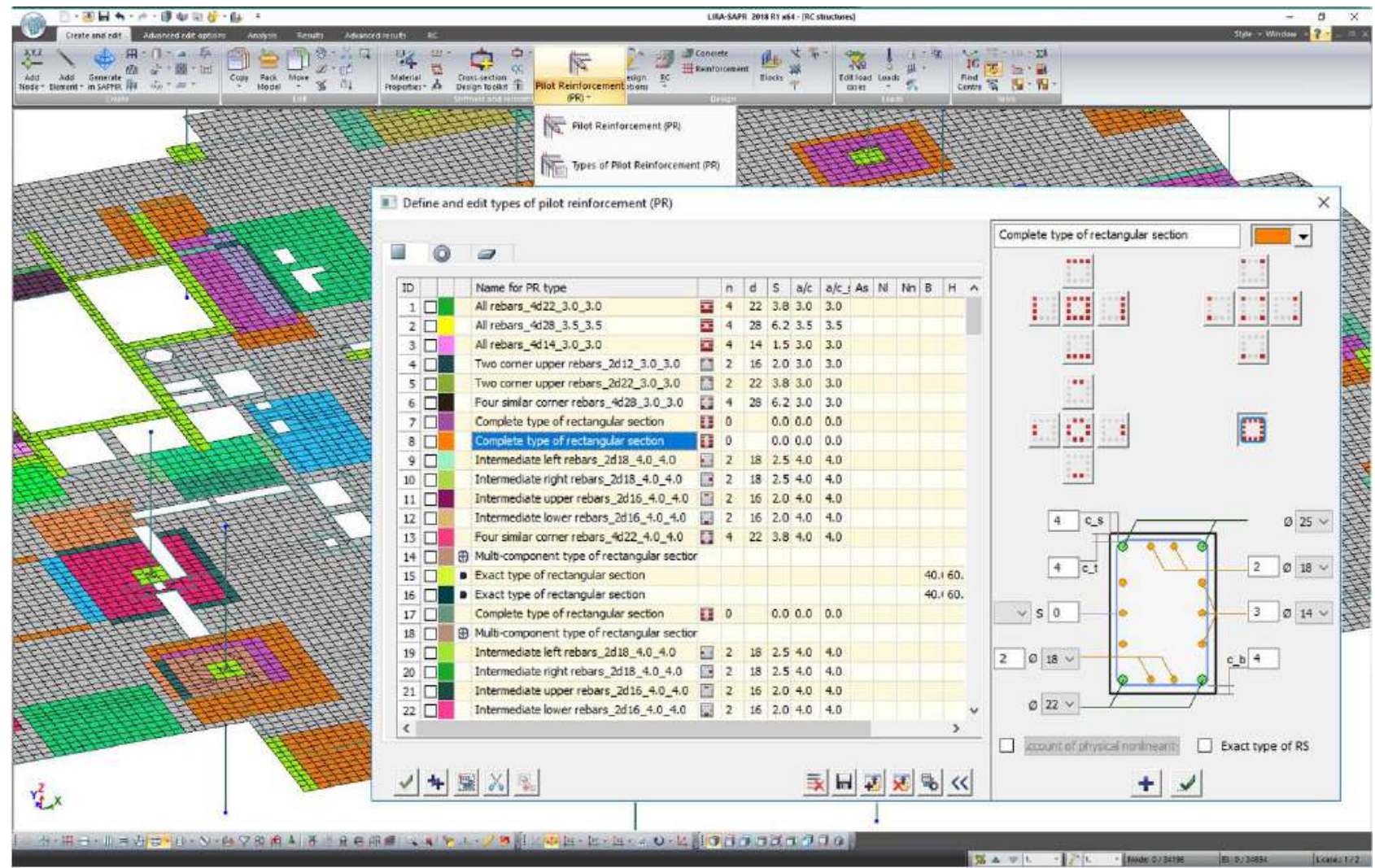

Figure 1. Generation of parametric types of specified reinforcement for elements of the model in LIRA-SAPR.

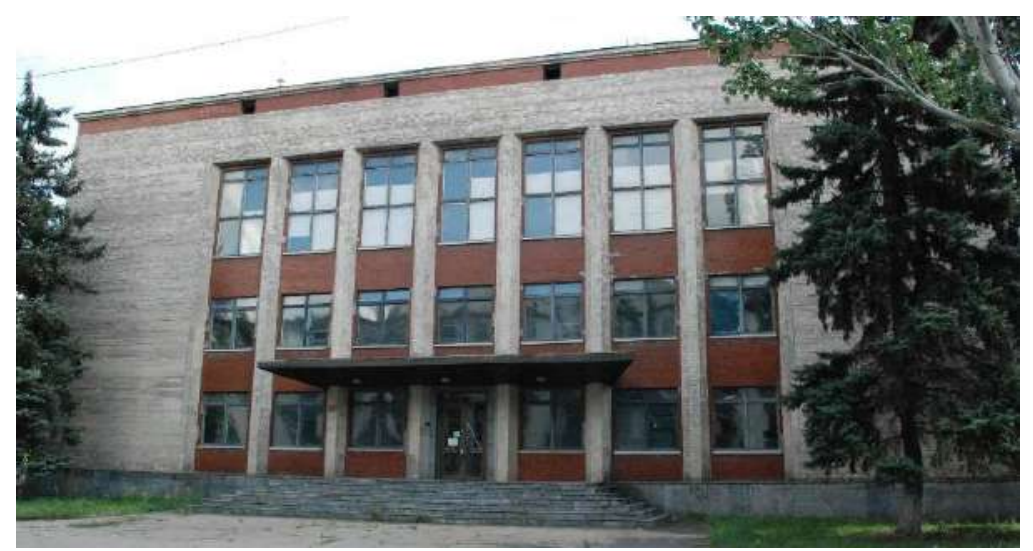

Figure 2. Building before reconstruction.

of the bars is determined. The required reinforcement area is selected for the superstructure part.

This method of analysis was used to estimate whether it is possible to reconstruct a 3-storey administrative building (Fig. 2).

The spatial rigidity of the building is provided by combined behaviour of the longitudinal bearing, transverse self-supporting walls and rigid bodies of floor slabs. During reconstruction of a non-residential building, it is proposed to remove existing brick partitions and install new ones. According to a survey of the building, conclusion is made that it could be reconstructed with a superstructure as the fourth storey. In design of this project, it was considered that the building is located in the existing residential area with its own basic facilities [11]. 


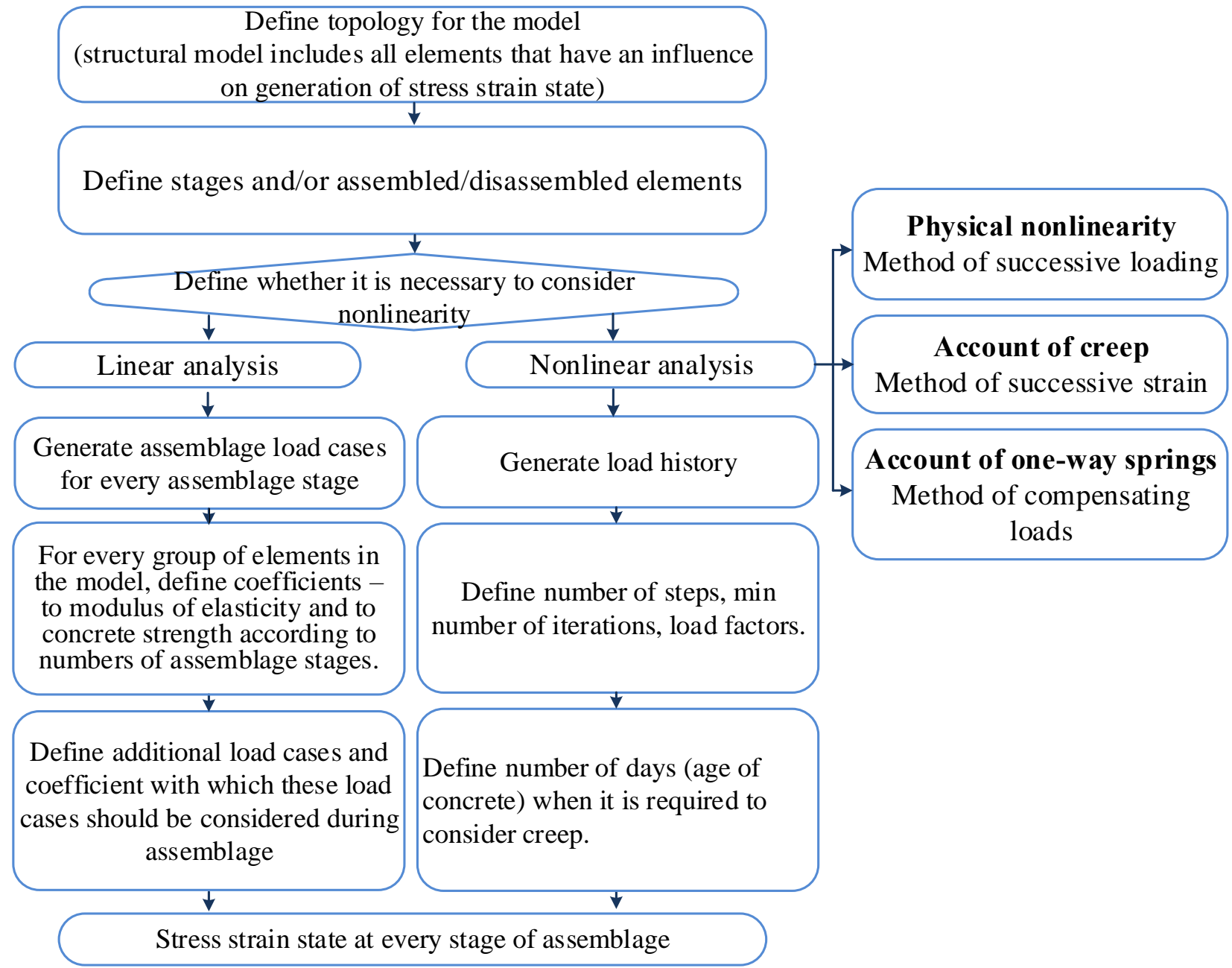

Figure 3. Algorithm of analysis with account of erection process.

Analysis was carried out in LIRA-SAPR with account of erection process. The general algorithm for analysis with account of erection process for linear and physically nonlinear problems is presented in Fig. 3.

First of all, design model of the whole object is generated; it includes all elements that influence the stress strain state: the main load-bearing elements of the object - columns, beams, slabs, diaphragms, and temporary elements formwork elements, struts, etc.

Then, for each stage of construction, all the structural elements that were erected or removed at the stage are indicated. Elements may be disassembled only once. Empty stages are allowed. The empty stage has the same elements as the previous stage. It is used only to define the load.
For each stage of assemblage you define loads (dead weight, assemblage loads) applied at this stage. Certain assemblage load should correspond to each stage of assemblage. Thus, the number of stages and the number of assemblage loads must be the same. Empty assemblage load cases are allowed. For example, a stage in which the elements of design model are only disassembled and no load is applied is considered as empty load case.

If necessary, correction factors are defined for each group of elements in the model - to the modulus of elasticity and to concrete strength in accordance with the numbers of assemblage stages. If information about the groups is not specified, then material properties remain the same at all stages. 


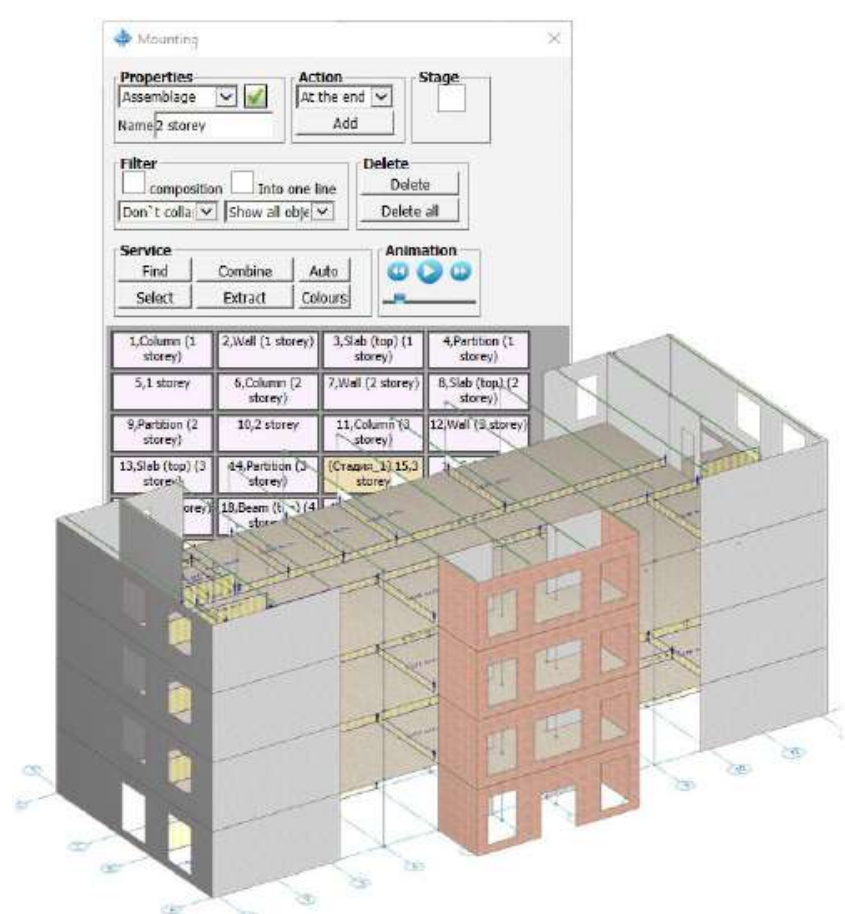

a)

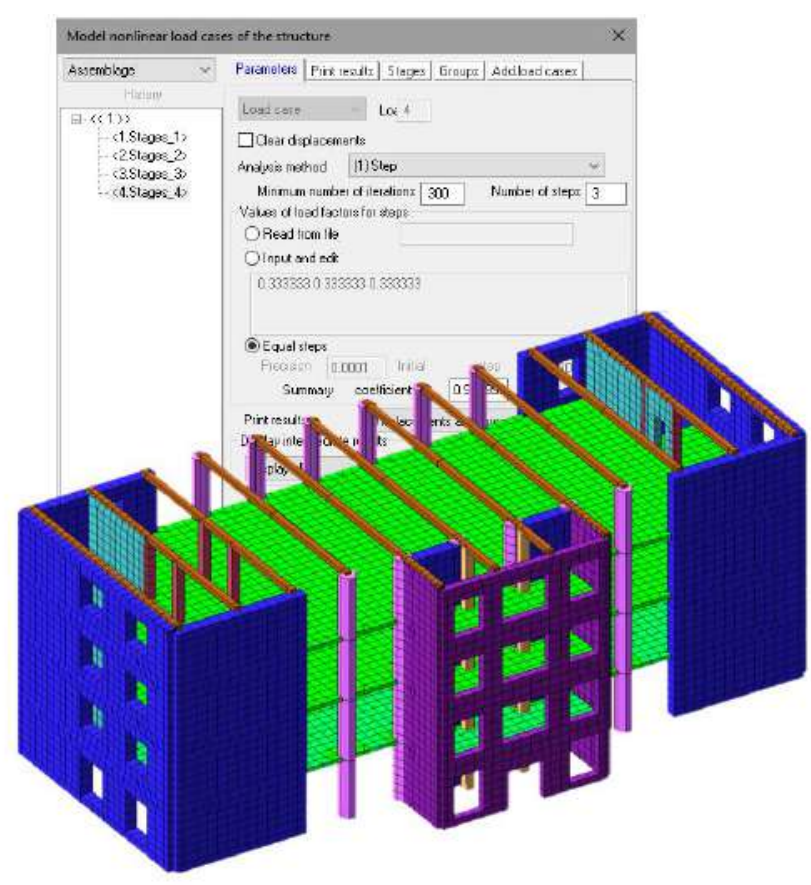

b)

Figure 4. Design model of the administrative building with account of assemblage stages:

a) in SAPFIR; b) in LIRA-SAPR.

For each stage you could also specify the numbers of additional load cases and the coefficients (including zero and negative ones) that should be considered during erection. Additional load cases are taken to mean load cases that contain loads from the storage of construction materials, from their movement within a storey or building, etc.

In addition to assemblage tables, you define parameters such as analysis method, number of stages, coefficients to load, etc. The load history is always considered.

After analysis by solver, the program computes the forces and stresses accumulated in the elements during erection process. By default, displacements of nodes are not accumulated in analysis; they are computed once more for each stage.

For this reconstructed administrative building, the following stages of assemblage are considered: the first stage is to assemble elements of the 1-3rd storeys; the second stage is to apply service loads; the third stage is to assemble elements of the fourth storey; fourth stage - to apply service loads (Fig. 4).
The following example demonstrates reconstruction of a hostel building. Wooden floor slabs are replaced with monolithic RC floor slabs, the opening is made for the whole height of the building.

The structural model of the building is a mixed frame: longitudinal and transverse frames of brick pillars and prefabricated reinforced concrete beams rigidly fixed in them; and loadbearing longitudinal and transverse walls that prefabricated reinforced concrete beams are supported with. Fig. 5 depicts general view of the hostel building before and after reconstruction.

To determine whether reconstruction and redevelopment are possible, a survey of the load-bearing structures of the building was carried out as well as numerical experiments to determine bearing capacity of the building structures. With the help of ASSEMBLAGE module in LIRA-SAPR program, wooden floor slabs were disassembled and reinforced concrete floor slabs were installed; rigid body of floor slab is replaced within entire area of the building (Fig. 6). 


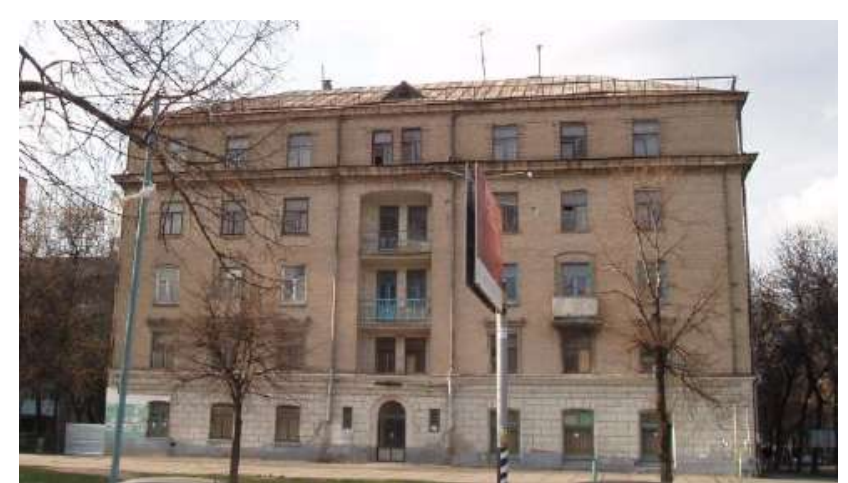

a)

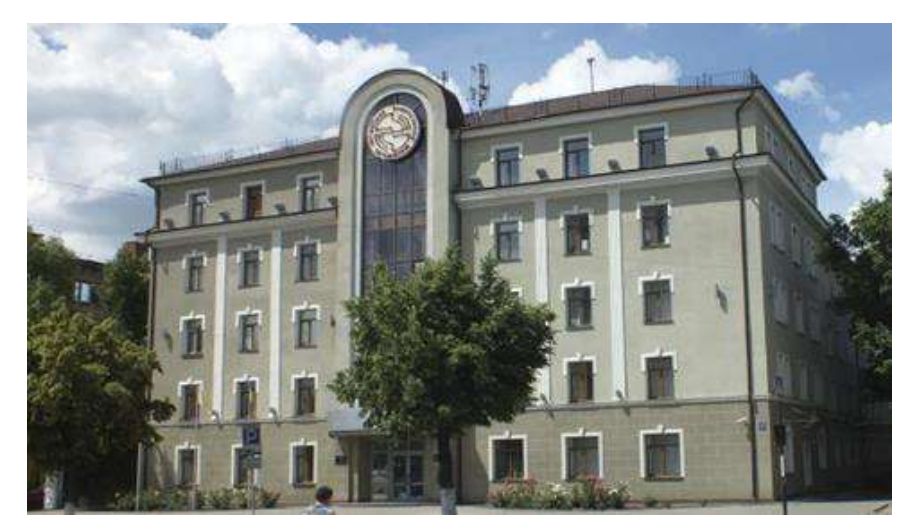

b)

Figure 5. General view of the hostel building:

a) before reconstruction; b) after reconstruction.

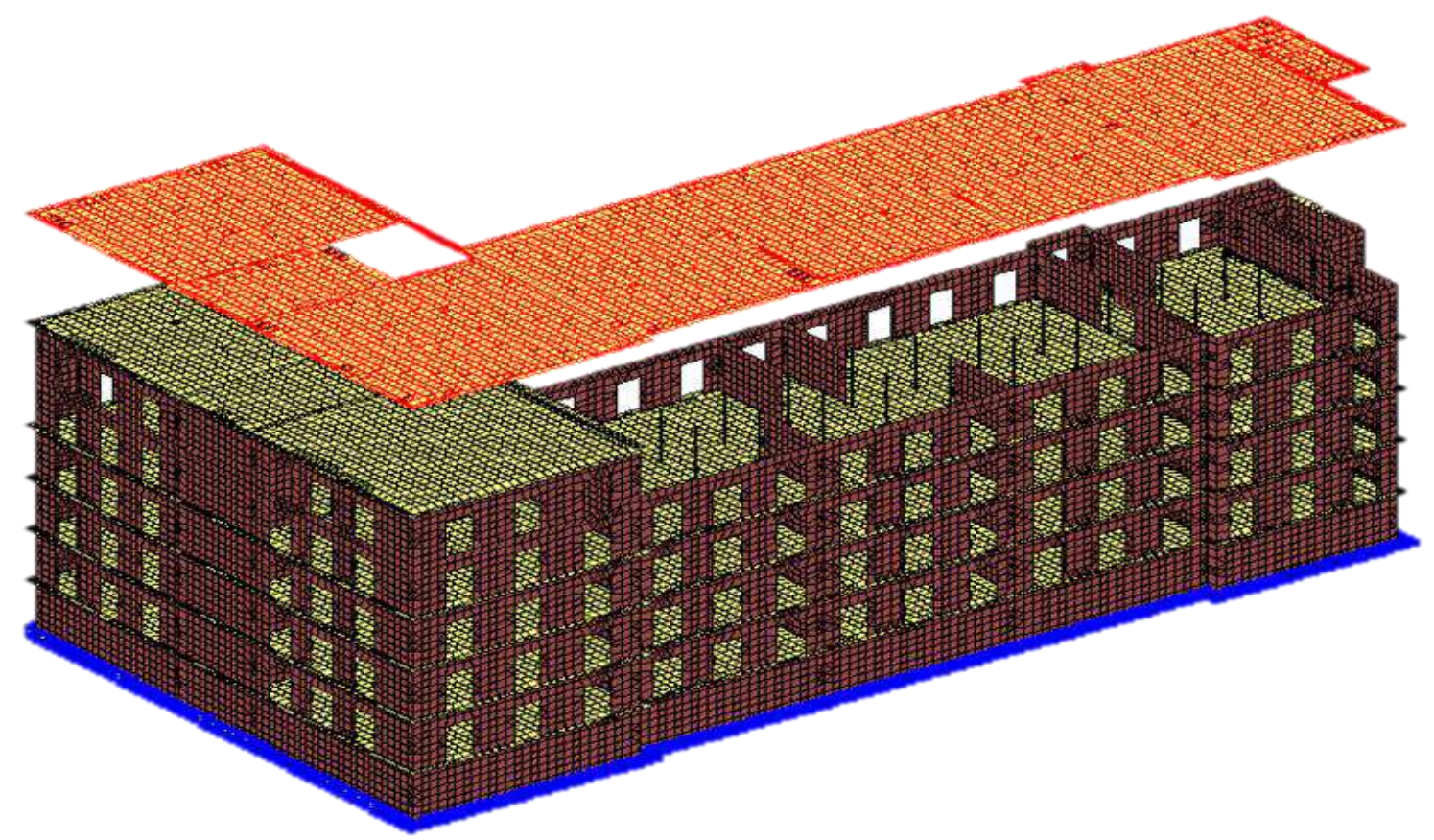

Figure 6. Design model of hostel (general view).

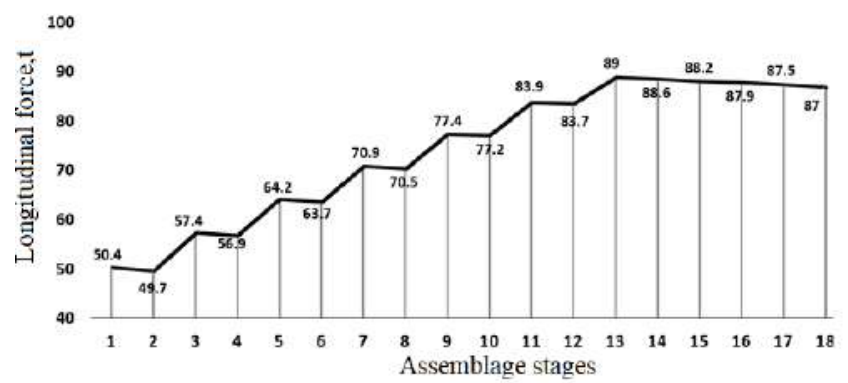

a)

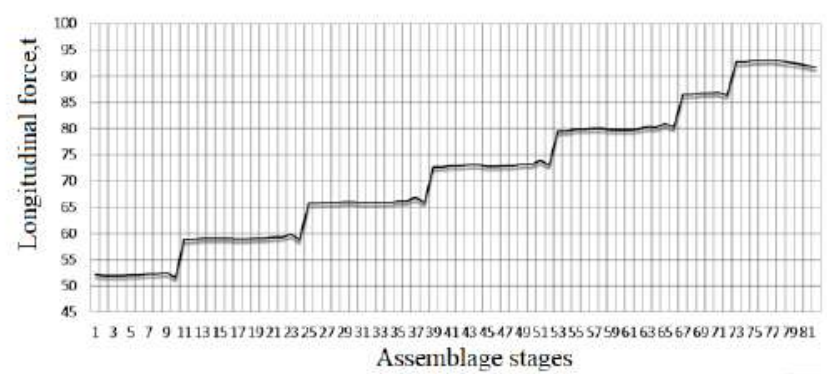

b)

Figure 7. Changes of longitudinal force in column of design model of the hostel:

a) 18 assemblage-disassemblage stages;

b) 81 assemblage-disassemblage stages. 


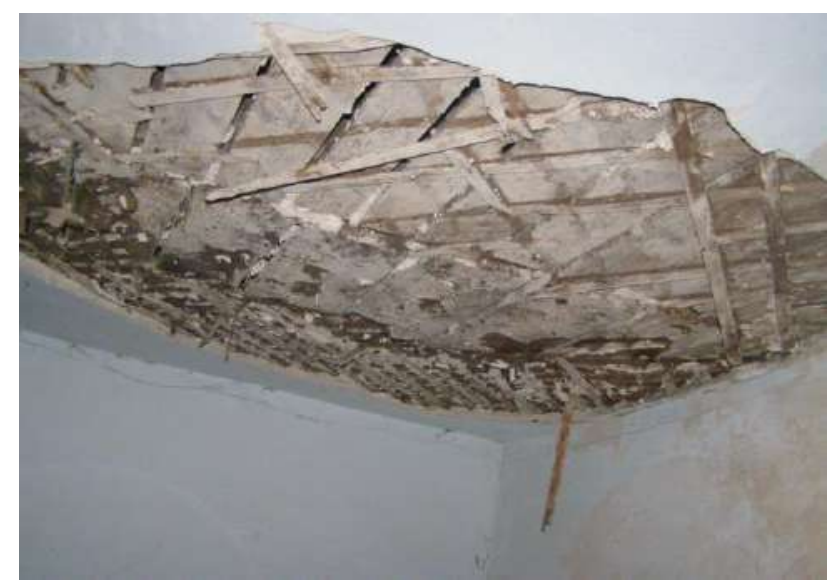

a)

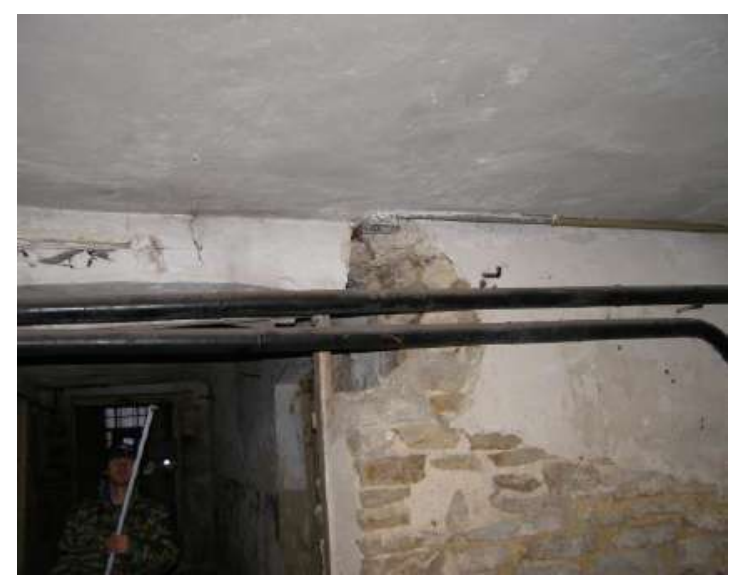

b)

Figure 8. Defects detected during evaluation of technical condition of the building structures: a) floor slabs got wet; b) load-bearing wall in the basement of the building is destroyed.

After analysis with account of assemblage / disassemblage process, the program evaluates changes of forces in the load-bearing structures during the reconstruction. For example, in one of the columns at level 0.0, the longitudinal force is changed from $49.7 \mathrm{t}$ (after disassemblage of the wooden floor slab at level $3.2 \mathrm{~m}$ ) to $89 \mathrm{t}$ (after installing the reinforced concrete floor slab at level $19.2 \mathrm{~m}$ ), it represents the difference 1.8 times.

Design model of the building was also studied. Every floor slab in the model was divided into 7 parts (according to the developed process list), it increased the number of assemblage / disassemblage stages up to 81 stages (Fig. 7). But obtained results did not significantly differ from the design model where floor slabs were assembled in enlarged details.

With such stage-by-stage simulation, it is convenient to evaluate the changes of the stress strain state in design model. So, it will be possible to provide detailed recommendations on the rational strengthening of structures in the reconstructed building and, if necessary, correct accepted design solutions during construction and assemblage.

For reconstructed buildings, it is very important to consider the damages and wear of the loadbearing structures identified during the technical checkup. If there are cracks and defects in the structures, it is necessary to simulate the structures and structural systems with account of accumulation of damages and structural destruction, reduction in stiffness properties of load-bearing elements. In such cases, it is important to determine the ability of damaged structural elements to take external load.

In the survey and evaluation of technical condition of building structures (that were carried out in order to determine its serviceability criterion and develop construction documents for strengthening of building structures and obtain certificate of a piece of architecture), serious defects were found: the load-bearing wall in the basement of the building was destroyed; floor slabs of the building got wet; cracks in the bearing walls of the building; destruction of the concrete cover and corrosion of reinforcement in monolithic gallery bulkheads, destruction of the plaster layer and corrosion of steel vaulted beams in the basement (Fig. 8).

Analysis of generated FE model of the building was carried out in LIRA-SAPR program with account of physical nonlinearity, based on the deformations and defects identified in the technical survey.

To consider reducing the strength properties of building materials, stiffness properties were modified in the design model. To be exact, modulus of elasticity is reduced, geometry of the cross-section is modified, several finite elements were ignore in analysis of design model. 


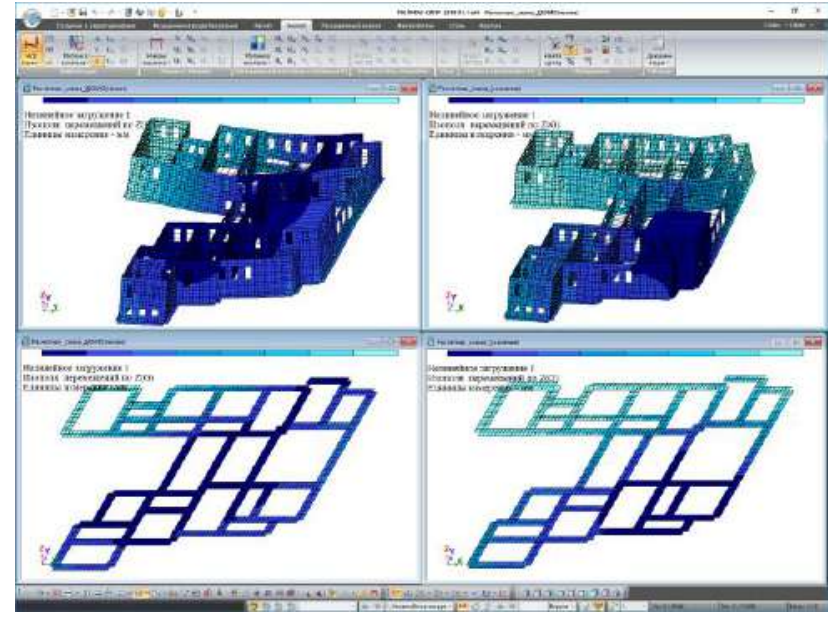

a)

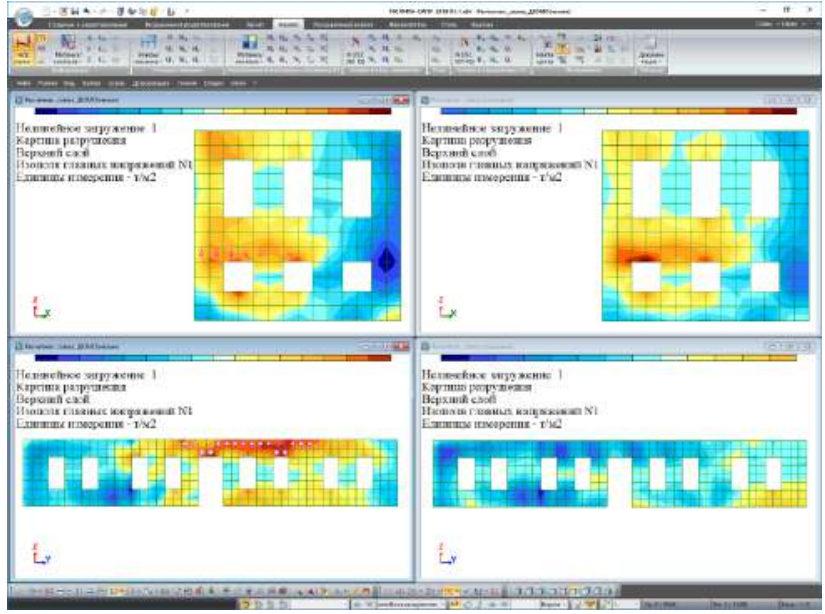

b)

Figure 9. Fragment of design model before reconstruction and after reconstruction

a) contour plots of displacements;

b) contour plots of of principal stresses and the pattern of destruction.
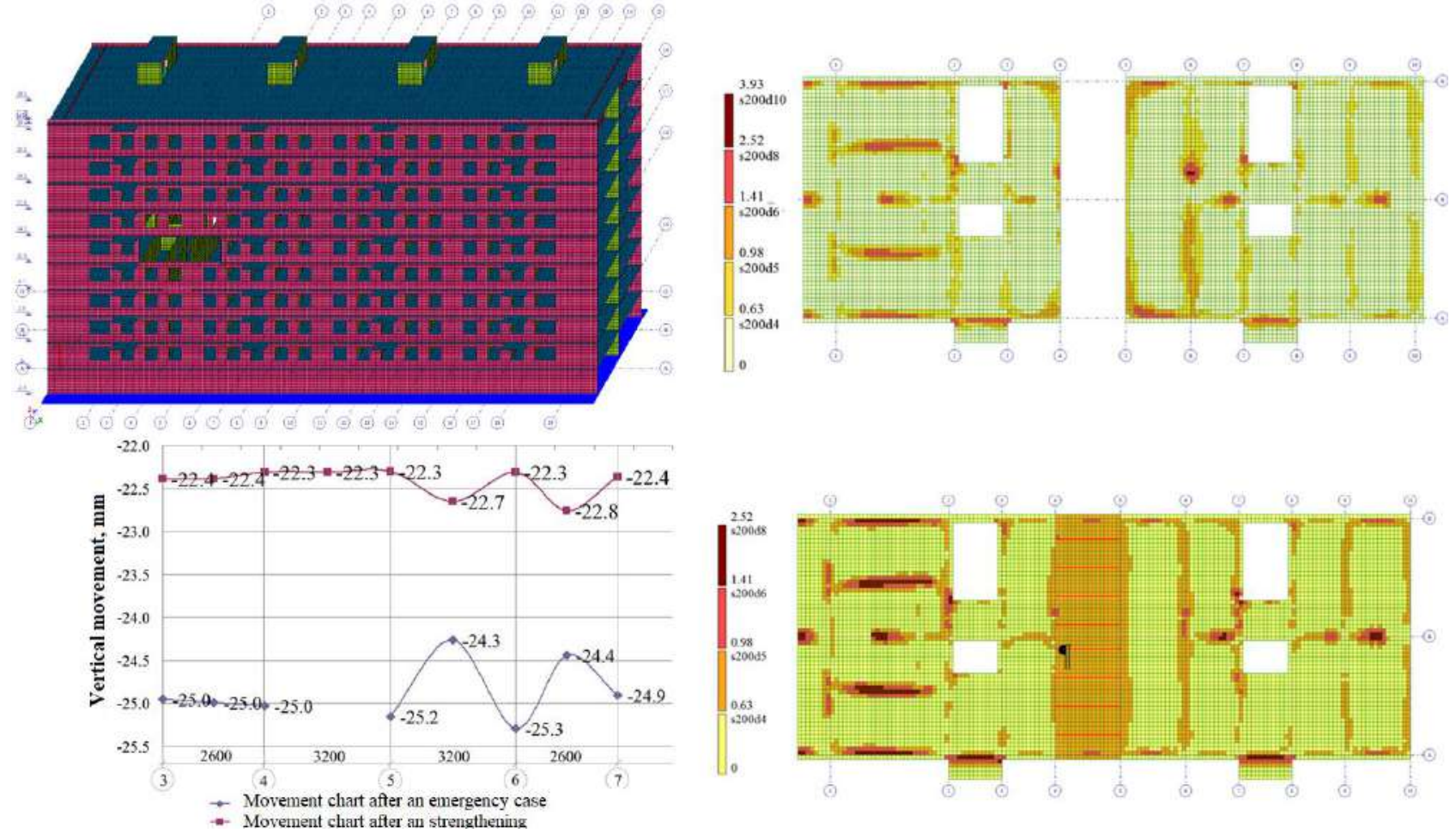

Figure 10. Results of numerical experiment and technical survey after explosion, a fragment of the reinforcement in the floor slab after the explosion and after strengthening.

In elements of design model of the building, there are stresses that exceed the design strength of materials of the structures. It causes crack generation and other defects that were also found in the technical survey of the building. According to analysis of design model before the reconstruction, measures to strengthen the structural elements were developed. Comparison of the stress strain state of the building before reconstruction and after strengthening is presented in Fig. 9. 
It is even more difficult to simulate such effects as an explosion, a fire inside a building, and other emergency situations. For example of such design model, there may be the model of a 9storey residential building in which a gas explosion occurred. Analysis of the stress-strain state of the frame in explosion was carried out; so adaptability of structures to loads beyond design basis is determined. It causes less material consumption during the strengthening and reconstruction of a residential building in emergency case (Fig.10).

\section{CONCLUSION}

Thus, in reconstruction of buildings, it is necessary to carry out several numerical experiments to determine the most useful technique to strengthen the load-bearing elements, especially if it concerns the superstructure of storeys, replacement of floor slabs, and reconstruction after accidents. To carry out numerical experiments in LIRA-SAPR program, the following procedure is proposed:

1. Design model of the building is generated according to results of the survey on technical condition of the building, available documentation or/and technical check with account of damage and wear of load-bearing structures. Bearing capacity of structures is determined.

2. Design model of the building is generated with account of proposed reorganization, redevelopment, modernization, erected superstructures, additions to building. Analysis of stress strain state is carries out after several numerical experiments with account of restoration, strengthening and replacement of building structures. The program identifies dangerous elements of structures or their parts. Recommendations are provided whether reconstruction is possible. Measures to strengthen the bearing structures are suggested.

Proposed algorithm allows the user to obtain quite accurate stress strain state of the elements of bearing structures of the object with account of all changes and to predict its behaviour in the future as well. Analysis of the stress strain state of design model enables the user to draw conclusions about effectiveness of certain variant of structures' strengthening during their reconstruction.

\section{REFERENCES}

1. Sluchai Razrusheniya Zdanij za Rubezhom v 2011-2013 Godah [Cases of buildings' failures abroad in 2011-2013] [Electronic resource]: RIA Novosti - access: http://ria.ru/spravka.

2. Gorodetsky A.S. Komp'yuternoe Modelirovanie Processa Vozvedeniya Stroitel'nyh Konstrukcij [Computer Simulation of Erection Process of Building Structures]. // Collection of research papers of Lugansk National University, issue "Technical sciences". Lugansk, Ed. "LNAU”, 2007, pp. 3-9.

3. Barabash M.S. Komp'yuternoe Modelirovanie Processov Zhiznennogo Cikla Ob"ektov Stroitel'stva [Computer Simulation of Life Cycle Process in Building Objects]. Kiev, "Steel”, 2014, 301 pages.

4. Gorodetsky A.S., Barabash M.S., Sidorov V.N. Komp'yuternoe Modelirovanie v Zadachah Stroitel'noj Mekhaniki [Computer Simulation in Problems of Building Mechanics. Study Guide]. Moscow, ACB Publishing House, 2016, 338 pages.

5. Banakh V.A. Statiko-Dinamicheskie Raschetnye Modeli Zdanij i Sooruzhenij v Slozhnyh Inzhenerno-Geologicheskih Usloviyah [Static-Dynamic Design Models of Buildings and Structures in Complex Geological Environment]. Zaporozhje, ZGIA, 2012, 334 pages.

6. Tkachenko V.B., Banakh V.A., Banakh M.S. Retrograde Simulation of Emergency 
and Deformed Objects in Urban Areas. // Web of Scholar, 2018, No. 3(21), Vol. 1, pp. 29-34

7. Perelmuter A.V., Slivker V.I. Raschetnye Modeli Sooruzhenij i Vozmozhnost' ih Analiza [Design Models of Structures and Options for Their Analysis]. Kiev, 'Steel', 2002, 600 pages.

8. Barabash M.S. Vliyanie Processa Vozvedeniya na Prostranstvennuyu Rabotu Nesushchih Sistem Zdanij [The impact of erection process on 3D behaviour of bearing systems in buildings]. // Construction, material science, mechanical engineering // Collection of research papers, Dnipro, PGASA, 2012, No. 65, pp. 29-34.

9. Barabash M.S. Metody Komp'yuternogo Modelirovaniya Processov Vozvedeniya Vysotnyh Zdanij [Methods of Computer Simulation for Erection Process in HighRise Buildings]. // International Journal for Computational Civil and Structural Engineering, 2012, Vol. 8, Issue 3, pp. 5868.

10. Gorodetsky A.S., Barabash M.S. Komp'juternoe Modelirovanie Processa Vozvedenija Stroitel'nyh Konstrukcij [Computer Simulation of Erection of Building Structures]. // Building mechanics and analysis of structures, 2014, Issue 5(256), pp. 28-33.

11. Ulybin A.V., Zubkov S.V., Fedotov S.D., Zakrevsky A.Y. Survey of Pile Foundations in Arranging Superstructures for Buildings. // Magazine of Civil Engineering, 2014, No. 4, pp. 17-26.

\section{СПИСОК ЛИТЕРАТУРЫ}

1. Случаи разрушения зданий за рубежом в 2011-2013 годах (электронный ресурс). РИА «Новости» - доступ: http://ria.ru/spravka.

2. Городецкий А.С. Компьютерное моделирование процесса возведения строительных конструкций. Сборник научных трудов Луганского национального университета, серия «Технические науки». - Л.: Изд-во «ЛНАУ», 2007, c. 3-9.

3. Барабаш М.С. Компьютерное моделирование процессов жизненного цикла объектов строительства. - Киев: Издательство «Сталь», 2014. - 301 с.

4. Городецкий А.С., Барабаш М.С., Сидоров В.Н. Компьютерное моделирование в задачах строительной механики. - М.: АСB, 2016. - 338 с.

5. Банах В.А. Статико-динамические расчетные модели зданий и сооружений в сложных инженерно-геологических условиях. - Запорожье: ЗГИА, 2012. $334 \mathrm{c}$.

6. Tkachenko V.B., Banakh V.A., Banakh M.S. Retrograde Simulation of Emergency and Deformed Objects in Urban Areas. // Web of Scholar, 2018, No. 3(21), Vol. 1, pp. 29-34.

7. Перельмутер А.В., Сливкер В.И. Расчетные модели сооружений и возможность их анализа. - Киев: Издательство «Сталь», 2002. - 600 с.

8. Барабаш М.С. Влияние процесса возведения на пространственную работу несущих систем зданий. // Строительство, материаловедение, машиностроение // Сб. научных трудов. - Днепропетровск: ПГАСА, 2012, № 65, c. 29-34.

9. Барабаш М.С. Методы компьютерного моделирования процессов возведения высотных зданий. // International Journal for Computational Civil and Structural Engineering, 2012, Vol. 8, Issue 3, pp. 5868.

10. Городецкий А.С., Барабаш М.С. Компьютерное моделирование процесса возведения строительных конструкций. // Строительная механика и расчет сооружений, 2014, Вып. 5(256), с. 28-33. 
11. Ulybin A.V., Zubkov S.V., Fedotov S.D., Zakrevsky A.Y. Survey of Pile Foundations in Arranging Superstructures for Buildings. // Magazine of Civil Engineering, 2014, No. 4, pp. 17-26.

Maria S. Barabash, Academician of the Academy of Construction of Ukraine, Director of "LIRA SAPR" Ltd, DSc (Eng.), Associate Professor, Professor of Department of Computer Technology Building, Educational and Scientific Institute of Airports, National Aviation University, 1, Kosmonavta Komarova, 03058, Kiev, Ukraine; phone: +38 (095) 286-39-90;

E-mail: bmari@ukr.net, http: www.liraland.ru; https://orcid.org/0000-0003-2157-521X,

Researcher ID: R-9181-2016.

Maryna A. Romashkina, PhD, Support Engineer of "LIRA SAPR" Ltd, Teaching Assistant of Department of Computer Technology Building, Educational and Scientific Institute of Airports, National Aviation University, 1, Kosmonavta Komarova, 03058, Kiev, Ukraine; phone: +38 (095) 931-52-50;

E-mail: romashkina.liraland@gmail.com; http: www.liraland.ru

ORCID ID: 0000-0002-7158-4037

Барабаш Мария Сергеевна, академик Академии строительства Украины, директор ООО «ЛИРА САПР», доктор технических наук, профессор кафедры компьютерных технологий строительства Учебно-научного института Аэропортов, Национального авиационного университета, 03058, Украина, г. Киев, проспект Космонавта Комарова, д. 1; тел: +38 (095) 286-39-90;

E-mail: bmari@ukr.net; http: www.liraland.ru

ORCID ID: 0000-0003-2157-521X;

Researcher ID: R-9181-2016.

Ромашкина Марина Андреевна, кандидат технических наук, инженер группы сопровождения ООО «ЛИРА САПР», ассистент кафедры компьютерных технологий строительства Учебно-научного института Аэропортов, Национального авиационного университета, 03058, Украина, г. Киев, проспект Космонавта Комарова, д. 1; тел. +38 (095) 931-52-50; E-mail: romashkina.liraland@gmail.com, http: www.liraland.ru;

ORCID ID: 0000-0002-7158-4037 